\title{
6
}

\section{SDSC in the Nineties: A Difficult Transition}

Paul Dibb

This essay was previously published in the 40th anniversary edition. It is reprinted here in its near original format.

In the 1990s, the Strategic and Defence Studies Centre (SDSC) underwent a difficult transition. The first 25 years of the Centre's work were concerned with the Cold War and its global and regional impact on Australia. In 1991, however, the Soviet Union disappeared and the Cold War suddenly ended. SDSC had to adjust rapidly to an altered international strategic environment and to new subjects for strategic analysis. In the mid-1990s, the government in Canberra changed and there was a move away from the defence ideas that the Centre had played a key role in developing from the early 1970s. During this decade, The Australian National University (ANU) also experienced significant financial difficulties, which had a serious impact on the SDSC budget and its ability to fund research on important issues.

The terrorist attacks on the United States of 11 September 2001, however, dramatically changed the international security environment and posed new challenges for the Centre's research and teaching agenda. It also brought about new sources of revenue. Thus, the early 
years of the new century have heralded a much brighter prospect for SDSC and it now finds itself in a much stronger position, both intellectually and financially, than ever before.

This chapter examines how SDSC handled the difficult transition from the end of the Cold War in 1991 to the so-called 'War on Terror' in 2001. It looks at what happened internationally and SDSC's response. It also analyses what happened in Australia and what this meant for the Centre's finances and research priorities. The central idea is to give the reader an understanding of the academic challenges facing SDSC, both in research and postgraduate teaching, and a feel for the problems of managing a small but prestigious institution in a period of difficult transition. This chapter draws heavily on the Centre's annual reports and regular newsletters over the decade of the 1990s, as well as my personal reflections as head of the Centre from 1991 to 2003.

\section{What Happened in the World and SDSC's Response}

On Christmas Day 1991, the red hammer and sickle was lowered from the Kremlin and replaced by the white, blue and red flag of Russia. Only with hindsight does the Soviet collapse appear predictable. Even Mikhail Gorbachev did not appear to understand fully what he was doing. And as Stephen Kotkin points out, it was amazing that this hyper-militarised Soviet Union did not attempt to stage even a cynical foreign war to rally support for the communist regime. ${ }^{1}$ Even if Soviet leaders had calculated that they were doomed, they could have wreaked terrifying havoc out of spite, or engaged in nuclear blackmail. Historically, such a profoundly submissive capitulation, as took place in the Soviet case, was a rarity. In the past, as Paul Kennedy has observed, none of the overextended, multinational empires ever retreated to their own ethnic base until they had been defeated in a great power war. ${ }^{2}$

1 See Stephen Kotkin, Armageddon Averted: The Soviet Collapse, 1970-2000 (New York: Oxford University Press, 2001).

2 Paul Kennedy, The Rise and Fall of the Great Powers (London: Fontana Press, 1989), pp. 567, 694. 
I dwell on this point for two reasons. The first is that the international academic community of Sovietologists, including those in Australia, did not predict that the Soviet Union was in deep trouble until the end (the intelligence communities in the United States, the United Kingdom and Australia had the same problem). The explanation, in my view, was over-specialisation - the inability to 'see the wood for the trees'. The second reason is that the Soviet Union was my focus of intelligence and academic study for 20 years, until 1985. It is commonplace for me to hear that the book that I published in 1986, entitled The Soviet Union: The Incomplete Superpower, predicted the end of that country. It did not: it merely pointed out that the Soviet Union was a power in difficulty and that, if Gorbachev's reforms failed, the Soviet Union risked falling out of the ranks of the world's great powers. ${ }^{3}$

Throughout much of the Cold War, Professor Des Ball made an outstanding contribution to our understanding of both Soviet and American nuclear targeting doctrine. In the early 1990s, he continued this by publishing articles on Soviet signals intelligence (SIGINT), and on the future of the global strategic balance and current developments in US strategic nuclear targeting policy. Coral Bell continued to work on great power and alliance issues: in 1994 she wrote about the new world order and the Gulf War, edited the book The United Nations and Crisis Management: Six Studies and several works on the Cold War in retrospect. The increasing dominance of the United States in world affairs was reflected in a book by Bell on the American ascendancy in international politics and diplomacy in the unipolar period, articles by Ball on the prospects for the US-Australia alliance, and works by myself on the question of whether America's alliances in the Asia-Pacific region would endure.

The biggest change, however, in the SDSC research agenda during the 1990s was a refocusing on the imperatives of understanding the new challenges to Australia's regional security. The end of superpower confrontation meant that much more attention could now be paid to the question of improving regional security dialogue and developing a new security architecture. A new range of issues surfaced in the regional strategic agenda, including major challenges that changes in the nature

3 Paul Dibb, The Soviet Union: The Incomplete Superpower, 2nd edn (London: Macmillan Press, 1988 [1986]), pp. 267, 278. 
of conflict presented to many nations in the development of their armed forces, as well as an increased demand for high-level education on strategic and defence policy issues in an era with no clear threats.

One central development, led by Ball, was the creation of the Council for Security Cooperation in the Asia-Pacific (CSCAP). This remarkable 'track two' initiative was created in 1993 and is now a well-established unofficial contribution to security confidence-building in the region. It should be recorded that Ball was not only instrumental at the creation of CSCAP but that he has laboured mightily for well over a decade now to ensure its success both at the regional level and within Australia.

Ball's publications on this subject began in 1991 with an analysis of confidence- and security-building measures as building blocks for regional security and continued through to the late 1990s with studies on preventive diplomacy and security cooperation in the Asia-Pacific region and studies on the evolving regional security architecture.

About 60 per cent of SDSC in-house publications (Canberra Papers on Strategy and Defence and Working Papers) in the decade of the 1990s were on regional security subjects. When in 1991 SDSC celebrated its 25th anniversary with a conference on 'Strategic Studies in a Changing World', it was significant that there was a particularly strong focus on north-east Asia, South-East Asia and the South Pacific. It was especially notable that all the heads, or deputy heads, of the strategic institutes in the Association of Southeast Asian Nations (ASEAN) region were at the conference and presented papers. It is also worth noting what the Governor-General, Bill Hayden, said about the Centre in opening the conference:

During some three decades of public life, I know that the Parliament, the military, the public service and the media have all benefited greatly from access to the informal views of the Centre ... one very positive aspect of your influence has been to inject the qualities of intellectual rigour, factual analysis and reasoned argument into a subject all easily prey to prejudice and superstition. ${ }^{4}$

4 Annual Report 1991 (Canberra: Research School of Pacific Studies, ANU), pp. 22-23. 
The proceedings of the 25th anniversary conference were edited as a book by Ball and David Horner. In that year, the Centre also initiated new research on India and was fortunate to secure the services of Sandy Gordon who, in 1995, produced the book India's Rise to Power in the Twentieth Century and Beyond.

The furtherance of security dialogue in the region and the development of concrete ideas for security-building measures gathered momentum. In 1993 I chaired the first security dialogue between Australia and China on behalf of the Department of Foreign Affairs. In 1994 I also chaired an informal meeting of 18 ASEAN Regional Forum (ARF) countries (again on behalf of Foreign Affairs) on practical measures for military and security cooperation and, in the same year, I published a jointly authored monograph with the Foreign Minister, Senator Gareth Evans: Australian Paper on Practical Proposals for Security Cooperation in the Asia-Pacific Region.

A major external review in 1995 of the Research School of Pacific and Asian Studies (as the Research School of Pacific Studies had been renamed the year before) noted that SDSC contributed to the Research School's 'high public visibility and considerable involvement with governments and non-government organisations in the region'. ${ }^{5}$ The Centre continued to remain at the forefront of developing new concepts for security planning in the region and, partly due to Ball's hard work, in 1996, ARF accepted that CSCAP had a legitimate role in promoting regional security. That year, SDSC also held its 30th anniversary conference on 'The New Security Agenda in the AsiaPacific' jointly with the International Institute for Strategic Studies (IISS). The conference was addressed by the Minister for Defence, the Minister for Foreign Affairs, the Shadow Minister for Defence, the Chief of the Defence Force and other senior officials, as well as the Chairman of the Council of IISS and its Director.

In 1996 SDSC was host to the 6th CSCAP Steering Committee in Canberra. The meeting was attended by over 50 representatives and observers from the Asia-Pacific region and Europe. In that year, Ball edited the book The Transformation of Security in the Asia-Pacific Region, as well as co-authoring Presumptive Engagement: Australia's Asia-Pacific Security Policy in the 1990s. Research on regional security 
was steadily expanded, with assistance from Department of Defence funding, to include the effect of population movements, security problems caused by environmental concerns, the relevance of RMA (revolution in military affairs) to regional countries, regional defence decision-making, the US-Japan relationship, Indonesian defence developments, China's foreign and defence policies, and developments in North Korea. SDSC gave assistance to regional countries with the preparation of defence white papers (for example, those of Thailand, the Philippines, Vanuatu and Papua New Guinea). A number of the Centre's academic staff wrote in journals such as Survival about the strategic implications of the Asian economic crisis in 1997 and 1998, while Alan Dupont wrote an Adelphi Paper on the effect of the environment on security in the region.

In 1999 Ball began his fine-grained research into security problems on the Thai-Burma border, which is the definitive work on this subject. The East Timor crisis in that year, and, more generally, the problems in Indonesia, dominated much research, with SDSC staff writing and commenting on the Indonesian armed forces, Indonesian politics, and the effect on security relations with Australia of Australia's intervention in East Timor. In 2000 Ball was honoured by being appointed co-chair of CSCAP as a whole. Particularly important publications in that year were his book Death in Balibo: Lies in Canberra and my co-edited book America's Asian Alliances, as well as Dupont's major book, East Asia Imperilled: Transnational Challenge to East Asia's Security, published the following year.

At the time of writing, in SDSC's 40th year, the Centre has adjusted to the new security challenges of the post-Cold War era and established a reputation for being the leading academic authority in Australia on Asia-Pacific security issues. It has introduced new research methodologies into the challenge of security confidence-building in the region and played a leading role in the creation of second-track dialogue and the initiation of so-called one-and-a-half track regional security exchanges. New areas of research have been initiated in the areas of terrorism and transnational crime while, at the same time, a more traditional focus has been retained on the question of US strategic primacy and the changing role of alliances in the Asia-Pacific region. A shortcoming that needs to be addressed is the Centre's lack of specific academic expertise on China, Japan and India. We were 
fortunate in 2001, however, to attract Ron Huisken back to SDSC from Defence - he brings formidable knowledge of the region, the US alliance, and nuclear proliferation issues.

\section{What Happened in Australia and SDSC's Response}

From the early days of its creation, SDSC was at the forefront of developing new ideas for Australia's defence policy. Tom Millar, Bob O'Neill, Jol Langtry, Des Ball and Ross Babbage were instrumental in developing ideas for a more independent Australian defence policy, as well as detailed analyses of the geography (and defence strengths and vulnerabilities) of the north of Australia. Much of this work was path-breaking and ahead of the policy work being done at that time in Defence. I wish to record here my debt to these colleagues for the way in which their scholarship greatly assisted me when I wrote the Review of Australia's Defence Capabilities in 1985-86. Rarely for any form of academic endeavour, they had to begin with what amounted to a clean sheet of paper when considering planning for the defence of Australia. Their pioneering work, together with studies directed by Sir Arthur Tange in the Defence in the 1970s, made my task infinitely easier.

Most Australians these days accept only too readily the obvious statement in the 2000 Defence White Paper: 'At its most basic, Australia's strategic policy aims to prevent or defeat any armed attack on Australia. This is the bedrock of our security, and the most fundamental responsibility of government. ${ }^{6}$ In many ways, the history of the idea of the defence of Australia had its genesis in SDSC. That is little understood these days, including in Defence.

In 1990, Babbage published the major book A Coast Too Long: Defending Australia Beyond the 1990s, which was described by the Minister for Defence Kim Beazley at its launch as 'a unique contribution to the defence debate in Australia'. ${ }^{7}$ Babbage also published a large monograph, The Strategic Significance of Torres Strait, which was prepared as a report by the Centre to the Minister for Defence. In the same year, Ball and Langtry edited the book The Northern Territory in the Defence

6 Defence 2000: Our Future Defence Force (Canberra: Defence Publishing Service, 2000), p. 29.

7 Annual Report 1990 (Canberra: Research School of Pacific Studies, ANU), p. 26. 
of Australia: Geography, History, Economy, Infrastructure, and Defence Presence, and the Centre published monographs on the management of weapons systems projects in Defence and the employment of air power in the defence of Australia. A major consultancy was undertaken for the Australian Army on the relevance of land forces in the defence of Australia. In 1991, a conference on 'Australia in Space' was also organised by SDSC. This was the first time that the civilian and military uses of space for Australian national purposes had been discussed by representatives from government, industry and academia.

SDSC is unusual in Australian academia in that it has undertaken policy-relevant research. With the agreement of ANU, I was adviser to two secretaries of Defence between 1991 and 2002. This involved giving high-level advice on strategic policy and force structure. It also involved preparing a consultancy report in 1995 on the future role and structure of the Papua New Guinea Defence Force. ${ }^{8}$ Other members of the Centre, including Stewart Woodman and Mike Gilligan, assisted New Zealand, the Philippines and Thailand with developing their strategic policy and defence white papers.

A major external review of the Institute of Advanced Studies, presented in September 1995, referred to the impact that the Research School has had among policymakers, and singled out SDSC for its 'significant role in changing the orientation of Australia's defence thinking away from forward defence to one which emphasised a high level of self-reliance within an alliance framework' ${ }^{9}$ Throughout the 1990s, SDSC maintained its position as the leading academic authority in Australia on strategic and defence problems. With the change of government in 1996, the Centre moved quickly to remain relevant to the current debate and to meet the requirements of government policymakers. Yet, both then and now, SDSC has always been willing to push the debate beyond political or official pronouncements (this was especially the case when Senator Robert Hill was Minister for Defence between late 2001 and early 2006).

8 Paul Dibb \& Rhondda Nicholas, Restructuring the Papua New Guinea Defence Force: Strategic Analysis and Force Structure Principles for a Small State (Canberra: Strategic and Defence Studies Centre, ANU, 1996).

91995 Annual Report, p. 78. 
In the late 1990s, reductions in ANU financing of SDSC resulted in a move by Research School of Pacific and Asian Studies (RSPAS) to not give preference to Australian research priorities; there was to be no funding for Australian research. The 1997 Annual Report of the Research School noted plaintively that research on Australian security was crucial to the Centre's work and to its influence in shaping official defence thinking. It asserted that ' $[\mathrm{r}]$ esearch on regional security, from an Australian standpoint, would be meaningless without a detailed understanding of Australian defence' ${ }^{10}$

In 1998 the Centre held a major international conference, 'Maintaining the Strategic Edge: the Defence of Australia in 2015', at Parliament House in Canberra. The conference attracted speakers from overseas, and three members of the Centre also presented papers. Despite the travails of ANU funding, SDSC continued its research on Australian defence policy, historical perspectives on current defence problems, Australian Defence Force (ADF) command arrangements and strategic and operational concepts, and Australia's maritime strategy. The corner was turned in 1999, such that the Centre could give increased attention to Australian defence. ${ }^{11}$ Research concentrated on future strategic and defence planning, the Defence budget, implications of regional engagement for the Army, the need for local support to sustain Air Force operations, the implications of the East Timor deployment, an analysis of the current capabilities of the ADF, and a study of the Defence secretary's role in Defence policymaking.

The decade ended on a high note when I was asked by the Secretary of Defence and the Chief of the Defence Force (CDF) to be the co-leader of the internal consultation team within the Department of Defence that supported the government's public discussion process leading to the development of its Defence White Paper, which was released in December 2000. Myself and Air Vice-Marshal Brendan O'Loghlin visited 47 Defence establishments and had 64 meetings with over 6,000 members of the ADF in a period of only six weeks. Discussion of strategic issues highlighted the consensus view that the defence of Australia was the primary role of the ADF and there was also strong support for engagement in the region. The ADF's force 'hollowness' was

10 Director's section, 1997 Annual Report (Canberra: Research School of Pacific and Asian Studies, ANU), p. 3.

111999 Annual Report (Canberra: Research School of Pacific and Asian Studies, ANU), p. 19. 
of great concern and people were also critical of Defence's acquisition record. The feeling of 'change fatigue' was widespread. Members of the ADF were not convinced of the true savings from commercialisation and felt the process had gone too far and was undermining military capability. There was a strong feeling that Defence leadership was not adequately addressing personnel problems.

Ball's edited book Maintaining the Strategic Edge: The Defence of Australia in 2015 was published by the Centre in 2000, and Horner completed his book Making the Australian Defence Force (volume 4 of The Centenary History of Defence series) in 2001, looking at the ADF's development as a joint force. Between 1998 and 2002, as an Army Reserve Colonel, Horner was the first head of the Army's Land Warfare Studies Centre while still being attached to SDSC.

The advent of a new Defence minister, Senator Hill, late in 2001 heralded the beginning of a wide-ranging — and sometimes destructive - debate for the next four years about whether the ADF should be primarily structured for the defence of Australia and regional contingencies or whether it should be a global expeditionary force, operating in a subordinate role to our US ally. SDSC played a key role in both the academic dialogue and the debate in the media. In this period, I wrote over 70,000 words on this subject, collected as Canberra Paper No. 161, Essays on Australian Defence. ${ }^{12}$ It was launched in July 2006 by Allan Hawke, the new Chancellor of ANU and former Secretary of the Department of Defence, who in his speech described SDSC as 'a national asset'.

\section{Military History at SDSC}

The study of military history at SDSC has a long and proud tradition, beginning with $\mathrm{O}^{\prime}$ Neill's seminal volumes on the official history of the Korean War. In the decade of the 1990s, Horner was recognised as Australia's leading military historian. He was made a full professor in 1999 (Professor of Australian Defence History) and was honoured with the appointment as the Official Historian of Australian Peacekeeping and Post-Cold War Operations.

12 Paul Dibb, Essays on Australian Defence, Canberra Paper No. 161 (Canberra: Strategic and Defence Studies Centre, ANU, 2006). 
Despite this, we struggled to have Horner's academic qualities recognised by RSPAS when, as noted earlier, it faced serious budget problems in the mid-1990s and decided that academic priorities for Australian subjects should go to the back of the queue. This view was misguided on at least three grounds: first, strategic studies cannot be undertaken on a purely geographical basis; second, strategic and defence studies is based strongly in history; and third, SDSC has always supported history with a strong policy relevance - not military history for its own sake.

Horner, who took up the post of research officer in SDSC in September 1990, began by undertaking an analysis of Australian defence command and organisation. By the following year, he and Woodman had produced the major book Reshaping the Australian Army: Challenges for the 1990s, which was produced under a consultancy agreement with the Australian Army. In 1992 Horner was an historical adviser to Prime Minister Paul Keating during his visit to Papua New Guinea and published a book on the ADF in the Gulf War. ${ }^{13}$ He was awarded a grant from the Australian Army for a history of Australian artillery (The Gunners: A History of Australian Artillery, published in 1995) and for a biography of Field Marshal Blamey (Blamey: The Commander-in-Chief, published in 1998), as well as from National Archives of Australia for a book on the War Cabinet (Inside the War Cabinet: Directing Australia's War Effort, 1939-1945, published in 1996). In 1994 Horner published The Battles That Shaped Australia, and was appointed editor of the Australian Army's history series.

In 1995 he was awarded a grant from the Department of Defence to undertake a study of Sir Frederick Shedden and his influence on defence policy, Defence Supremo: Sir Frederick Shedden and the Making of Australian Defence Policy (2000). He also wrote a book with Ball, Breaking the Codes. This is a formidable publishing achievement and Horner is to be warmly congratulated on his serious approach to military history and his outstanding productivity. I look forward to reading what I am sure will be a profoundly good official history of Australian peacekeeping. 


\section{Education and Training at SDSC}

SDSC has a rather chequered history when it comes to education and training. This is because ANU policy towards postgraduate education has varied over time and the attitudes of some of our academic colleagues towards training has been one of disdain. External interest has also varied greatly; at present it is at a high point for both $\mathrm{PhD}$ and Master's education and we are hard pressed to keep up with demand. Yet, in the late 1990s, SDSC was told by Defence that it had no interest in postgraduate qualifications in strategic and defence studies, as distinct from short training courses and workshops.

In the early 1990s, the graduate program in strategic and defence studies, coordinated by Leszek Buszynski, had 12 students, including two from Indonesia, one from Malaysia, one from Singapore and two from New Zealand. ${ }^{14}$ The program was refined under my direction to reflect greater focus on the region and to place more emphasis on Australian defence policy formulation. All members of the Centre were involved with the program and, in addition to Buszynski, specific courses were conducted by Woodman and Gilligan. In 1992 two doctoral students joined the Centre and this number grew to four by 1994.

Master's students increased to 20 in 1993 and stayed at that level for the following two years. In a major initiative, agreement was reached for a joint Master's program with the Singapore Armed Forces Training Institute to commence in $1995 .{ }^{15}$ Woodman was appointed director of graduate studies at SDSC from early 1994 in succession to Buszynski, who took up an appointment at the International University of Japan. Woodman introduced a new unit entitled 'Defence Planning and

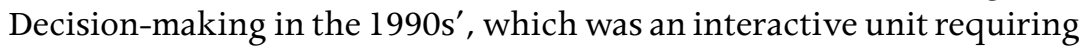
students to prepare for, and perform in, realistic policymaking situations. SDSC also began to conduct ad hoc courses for government departments and officers from foreign countries. By the late 1990s, however, we decided to terminate the Master's program because of dwindling numbers and Defence's lack of interest in providing financial support.

14 Annual Report 1991, p. 22.

151994 Annual Report (Canberra: Research School of Pacific and Asian Studies, ANU), p. 53. 
A decision was made in June 2001 to bring Babbage back to SDSC as an adjunct professor to reinvigorate the Master's program in a major way. He did this very well, bringing great dynamism and energy to expanding the Master's program to operate in Australia as well as in a great many overseas nodes. Since then, Robert Ayson, the Director of Graduate Studies, and his highly competent team have rationalised the Master's program to focus essentially on teaching in Australia. The Centre expanded to teach about 90 Master's students and $12 \mathrm{PhD}$ students. This is an all-time record for SDSC and it has made a major difference to our reputation as an academic centre of excellence in postgraduate studies. Under Professor Hugh White's guidance, we are now also delivering a major new training program to Defence's graduate trainees.

\section{The State of SDSC Finances}

SDSC finances have rarely been strong - we have always been a small organisation operating on a shoestring budget. From time to time, we have been able to raise external sources of funding, yet in my tenure as head I always considered that we needed to be careful because of the sensitive nature of the topics we research and the fact that it is all too easy to be seen to be beholden to the particular source of funds being offered. It is more prudent to politely refuse funding that could be perceived to be tainted, even if there are no obvious strings attached.

When I took over managing SDSC from Ball in 1991, ANU funding of the Centre was at its highest point, but I immediately took steps to broaden and strengthen its financial base. I approached the then Secretary of Defence, Tony Ayers, who undertook to double Defence's contribution to SDSC with a commitment to endeavour to maintain that level of funding for four years. ${ }^{16}$ In 1995, Defence was providing just under half the Centre's funds. ${ }^{17}$ This funding enabled us to appoint a new visiting fellow and it also placed the graduate program on a more sound financial base. Defence, the Ford Foundation, the New Zealand Ministry of Defence, British Aerospace Australia, Rockwell and Boeing all provided student scholarships and other support

16 Annual Report 1992, p. 28.

171995 Annual Report, p. 80. 
for the graduate program. ${ }^{18}$ The CSCAP program, whose Australian office is located in SDSC, was supported by grants from Foreign Affairs, Defence, Tenix Defence Systems, Raytheon International and Australian Defence Industries. I believe that our financial success in this regard reflected our academic performance in developing new ideas for regional security at a time of great international strategic change and in ensuring that the Centre's research was more policy relevant.

In 1994, SDSC was successful in gaining a National Priority Reserve Fund grant from the Department of Employment, Education and Training (now the Department of Education, Science and Training (DEST)) to fund research on security issues in north-east Asia, while substantial funds were also provided by the Department of Foreign Affairs and Trade for work on regional confidence-building measures. ${ }^{19}$ This enabled us in 1994 and 1995 to engage four new staff members to concentrate on various aspects of regional security. Faced by restrictions on the availability of ANU funding, the Centre successfully expanded to an academic and research staff of 13, even though there were only three ANU-funded positions. ${ }^{20}$

The period from the early to the late 1990s was a time when half a dozen or more sources of external funding generated an increasingly robust academic research agenda for the Centre. This changed in the late 1990s as ANU funding was progressively cut and we subsequently also lost a major part of our Defence funding due to the creation of the Australian Strategic Policy Institute (ASPI) in 2001, as well as the fact that we had terminated our Master's program at the end of 1997 due to lack of interest in Canberra. We had to reduce our academic staff from seven to five and our support staff from six to four by the end of 1997. ${ }^{21}$ Those of us who earned consultancy income were able to cushion the impact of these cuts on the Centre to some extent by subsidising academic endeavours (such as conferences) or making financial gifts to ANU that could then be reallocated according to donor priorities.

\footnotetext{
181993 Annual Report (Canberra: Research School of Pacific Studies, ANU), p. 28.

19 See 1993 Annual Report, pp. 28-29 and 1995 Annual Report, p. 81.

201995 Annual Report, p. 81.

211996 Annual Report (Canberra: Research School of Pacific and Asian Studies, ANU), p. 77.
} 
As SDSC entered the new century, its finances improved once again, although they can hardly be described as robust. White has been successful in obtaining Defence funding for a new post-doctoral position, as well as PhD scholarships and the new Defence graduate training program mentioned earlier. Funding from ANU, however, continues to be tight. We are fortunate that visiting fellows such as Admiral Chris Barrie, Coral Bell, Richard Brabin-Smith, and the Hon. Derek Quigley provide their services to us free of charge. We are also fortunate to have the services of such experienced people as John McFarlane, Alan Stephens, Ross Thomas, Clive Williams and Derek Woolner. It is this mixture of academics and former senior Defence officers that gives SDSC its great depth of both theory and practice, despite the periodic vicissitudes of our financial position.

\section{The Challenge of Managing SDSC}

As a former senior Defence bureaucrat, I cannot say that I found my 1991 transition to managing SDSC particularly easy. There were three reasons for this: the first was the precarious nature of SDSC finances; the second was the denigratory attitude of some of our academic colleagues to the work of the Centre; and the third was my reaction to the overly bureaucratic decision-making processes at ANU.

The challenge of managing SDSC finances is perhaps best reflected in a story from my first day as head of the Centre. The previous day I had left my position as Deputy Secretary in the Department of Defence where I considered no expenditure under the sum of $\$ 20$ million. I knew that the change would be painful - but little did I suspect that the first account I had to sign was $\$ 20$ for an afternoon tea! The more serious challenge was that SDSC had little clout in the 1990s when it came to academic in-fighting for a share of the Research School's declining budget. The fact that we were a small Centre, as distinct from a full-blown academic department, counted against us - as did the nature, I suspect, of our academic work.

This brings me to the problem of negative attitudes towards SDSC. The nature of our work makes it distasteful to some of our colleagues and, they allege, not worthy of serious scholarship. Ball brought to my 
attention some observations about the Centre by a visiting professor of international relations to the then Director of our Research School in 1988. This professor asserted that:

the work of SDSC, or much of it, seems more apt for a military staff college than a university. It should be vigorously cut back. Strategic studies are an integral part of IR, and should be taught as such in a university ... the technical aspects of strategy are not fit meat for a university ... there is a large SDSC covering an area that is widely acknowledged internationally not to be one of intellectual innovation or growth now compared with the 1950s and 1960s. ${ }^{22}$

Lest it be thought that this attitude was merely ancient history, I met the full force of academic prejudice almost as soon as I took over as head of SDSC. Professor Andrew Mack and his colleague Richard Higgott, both of the International Relations department within our own Research School, referred to the staff of SDSC as 'bomb-fondlers'. More seriously, they mounted a concerted effort to undermine the Centre as, under my guidance, we became more focused on policyrelevant research both in the area of Australian defence and regional security. The problem was that, as a small Centre, we were a part of the Division of Politics and International Relations and the divisional convener was Mack. He effectively managed the finances of the division as a whole and, hence, the allocation of money between International Relations, the Department of Political and Social Change, and SDSC. As I proceeded to raise more external funding (mainly from Defence), Mack started cutting SDSC's share of the divisional budget and made it clear he would be making more substantial cuts.

There was also a growing rift intellectually, with International Relations moving away from the predominant realist paradigm under professors Hedley Bull and J.D.B. Miller (as well as professorial fellows Millar and $\mathrm{O}^{\prime}$ Neill) to a greater focus on theoretical approaches. ${ }^{23}$ The differences also resulted in petty quarrels over accommodation in the H.C. Coombs building. This rift culminated in the decision by

22 A.J.R. Groom, Professor of International Relations at the University of Kent at Canterbury; Co-Director of the Centre for the Analysis of Conflict; and Vice-Chairman, British International Studies Association, made these remarks in a paper entitled 'Some Observations on the International Relations Department, Research School of Pacific Studies', 15 Aug. 1988 (personal papers of Professor D.J. Ball).

23 Paul Dibb, 'On Relations Between SDSC and IR', submission to the Review of International Relations at ANU, 14 May 1999 (personal papers of Professor P. Dibb). 
the then Director of RSPAS in 1994 to move SDSC from the Division of Politics and International Relations to become a separate Centre administered in the Director's unit. ${ }^{24}$ SDSC also moved out of the Coombs building to accommodation in Acton House. This, of course, only served to increase our sense of intellectual separation from the mainstream of RSPAS.

There can be no gainsaying of the void between policy-relevant work and 'pure academic work'. Some of our colleagues seem to continue to be not entirely comfortable with what SDSC does, although let me stress that this is not the stance of the current Director of RSPAS or his predecessor. And there can be no doubt that relationships with International Relations have greatly improved under the stewardship of Professor Chris Reus-Smit and his senior academic colleagues (one of whom happens to be one of my best friends). The hatchet should be well and truly buried by the time we move into shared accommodation in the new Hedley Bull Centre for World Politics in 2008 .

The third issue I want to raise is the problem of management in a university bureaucracy. When I worked in Defence, I thought it was one of the most ponderous organisations conceivable. I was wrong; university bureaucracies 'take the cake'. I soon discovered that universities consist of interminable meetings, with little in the way of hard conclusions, and endless, suffocating pieces of bureaucratic paper. The fact is that most academics are not good (or comfortable) with administration or pushing through unpalatable decisions in committee. I recognise, of course, that the collegiate nature of the academic faculty requires decision by consultation and consensus. Yet I have to say that I found it surreal how colleagues on the Faculty Board and Strategy Committee refused to contemplate cuts to the Research School's research priorities as the ANU budget was being slashed by the government. The reasoning from some colleagues was 'the government dare not cut us any further'. It did, and eventually we had to excise a much-valued area of academic research, Pre-history and Quaternary Dating, and transfer it to another part of ANU. My experience in other university committees, such as the Board of the Institute of Advanced Studies, was of huge numbers of people

241994 Annual Report, p. 53. 
engaged in endless discussion. I also found the university's hiring and firing regulations to be time-consuming, especially with regard to support staff.

I had clearly come from the wrong background, and I think some of my academic colleagues saw my impatience as resulting from what they perceived as me not being 'a real academic'. But Ball, who is indeed 'a real academic', experienced exactly the same frustrations when he managed SDSC. In 1991 he wrote some notes about leadership for a talk that he presented at the ANU conference 'Leadership in a Changing Context'. He stated very clearly that being head of SDSC was a frustrating and debilitating experience because ANU had overburdened itself with unnecessary and trivial administrative and bureaucratic practices and processes. ${ }^{25} \mathrm{He}$ found that he was spending about three quarters of the week working on the administrative and other duties expected of a head. Ball acknowledged that academics are, in general, neither good administrators nor good crisis managers. He observed that the criteria for academic success - good teaching and research abilities and a good publications record - are essentially irrelevant to the duties of administration and crisis management. ${ }^{26}$

There can be no doubt that there is much unnecessary bureaucracy and administrative minutiae in university life these days. Not all of this is the fault of ANU: the demands of DEST and the Australian Research Grants Committee to fill in endless forms are truly daunting. In the latter case, it was sufficient to put me off ever applying for an Australian Research Council grant.

We run the risk of forgetting that the prime purpose of the heads of departments and centres within ANU is to exercise leadership with respect to their disciplines in Australia. Only a head who has an active research program can command the intellectual respect of colleagues that is necessary to the exercise of academic leadership. As Ball observed, 'the Head of SDSC has a special responsibility to provide leadership with respect to issues of national importance' ${ }^{27}$

25 Desmond Ball, 'Leadership: Expectations of Heads', notes prepared for a talk presented to a conference for university heads in the faculties and the institute on 'Leadership in a Changing Context', organised by the Centre for Educational Development and Academic Methods (CEDAM), ANU, Batemans Bay, 1-2 May 1991 (personal papers of Professor D.J. Ball).

26 Ball, 'Leadership: Expectations of Heads'.

27 Ball, 'Leadership: Expectations of Heads'. 
ANU cannot be a cloister; basic research and freedom of academic inquiry are essential to the purpose of the university. However, they flourish best when tested against the issues of the real world, especially in our chosen field of endeavour - strategic and defence studies. The Secretary of Defence, Tony Ayers, argued this well when he wrote to the ANU Chancellor in July 1996:

The Centre brings much credit to the University for its contribution to the understanding of defence matters in the Australian community and in our region ... The Centre's excellent reputation in the region has ensured continuing participation in its programs by officers and civilian defence planners from regional countries. This helps to promote a rational and disciplined approach to defence policymaking in neighbouring countries. From the perspective of Australian Defence personnel development, the Centre's courses, programs and publications have directly benefited Australian Defence Force officers and civilian staff. ${ }^{28}$

This does not mean that SDSC should only focus on practical defence policy issues. We must continue to be grounded in academic scholarship on the security of our region and the contending theories of strategic studies. But we should not fall into the trap of modish academic fashion: for example, the so-called 'War on Terror' is not the same existential threat to the survival of the nation-state as global nuclear war would have been between the Soviet Union and the United States.

One final thought concerns SDSC's position in a competitive world. The fact is that there is now a proliferation of well-funded new research organisations in Australia: they include ASPI, the Lowy Institute for International Policy, the International Security Program at the University of Sydney, as well as the Kokoda Foundation. SDSC does not receive such lavish private sector or government funding and, as illustrated above, constantly operates on a financial shoestring. But one of our comparative advantages is that we operate within the university system where there are no financial strings attached - we can be frank in what we say on any subject without fear of angering our sources of funding. Our other big competitive advantage is that we have the most experienced collection of senior academics (including four professors) and former senior military officers and Defence officials anywhere in Australia (including a former Chief of the Defence Force 
and three former deputy secretaries of Defence). This lends tremendous prestige to our publications program and to our postgraduate teaching - a prestige that is not comparable elsewhere in Australia. Yet we must not rest on our oars: SDSC successfully came through the difficult transition of the 1990s stronger than ever. I have every confidence that, under White's leadership, SDSC can look forward to a continuing bright future as Australia's leading academic centre in strategic and defence studies. 
This text is taken from A National Asset: 50 Years of the Strategic and Defence Studies Centre, edited by Desmond Ball and Andrew Carr, published 2016 by ANU Press, The Australian National University,

Canberra, Australia. 